\title{
EFEKTIVITAS MODEL PEMBELAJARAN JIGSAW DALAM PEMBELAJARAN IPA FISIKA PADA SISWA SMP NEGERI 28 BANDAR LAMPUNG
}

\author{
Bernadeta Swahyuning Kasih, I Dewa Putu Nyeneng, I Wayan Distrik \\ Program Studi Pendidikan Fisika, Universitas Lampung \\ Email: bernadetay@gmail.com
}

Diterima: 8 Juni 2018. Disetujui: 4 Juli 2018.

\begin{abstract}
Abstrak
Masalah hasil belajar IPA Fisika di SMP N 28 Bandar Lampung merupakan masalah yang harus dicari solusinya. Model pembelajaran kooperatif tipe Jigsaw diharapkan dapat menjadi solusi atas masalah tersebut. Sampel penelitian ini adalah siswa kelas IX B dan IX C di SMP N 28 Bandar Lampung. Desain penelitian yang digunakan adalah Eksperimen semu dengan desain Pretest-Posttest pada kelompok kontrol. Hasil penelitian menunjukkan bahwa terdapat pengaruh penggunaan model pembelajaran kooperatif tipe Jigsaw terhadap hasil belajar siswa. Hal tersebut dapat dilihat dari hasil uji Independent Sample T-Test, nilai Sig (2-Tailed) kurang dari 0,05 . Model pembelajaran kooperatif tipe Jigsaw juga mampu meningkatkan hasil belajar siswa dengan nilai rata-rata $\mathrm{N}$-Gain pada kelas eksperimen sebesar 0,79 dengan kategori tinggi, sedangkan pada kelas kontrol sebesar 0,61 dengan kategori sedang.
\end{abstract}

Kata Kunci: jigsaw, hasil belajar, pengaruh.

\begin{abstract}
The problem of learning outcomes of Natural Sciences Physics at SMP N 28 Bandar Lampung is a problem that must be sought a solution. Jigsaw type cooperative learning model is expected to be a solution to the problem.. The sample of this research are the students of class IX B and IX C at SMP N 28 Bandar Lampung. The research design used was Quasi Experiment PretestPosttest Control Group Design. Data were analyzed using Independent Sample T-Test. The result of the research shows that there is effect of cooperative learning model-Jigsaw type to student learning result. It can be seen from the result of Independent Sample T-Test, Sig (2-Tailed) less than 0,05. Cooperative learning model-Jigsaw type able to improve student learning outcomes with the average value of $\mathrm{N}$-Gain in the experimental class is 0,79 with high category, while the control class is 0,61 with medium category.
\end{abstract}

Keywords: jigsaw, learning outcomes, effect.

\section{PENDAHULUAN}

Pendidikan merupakan salah satu hal penting untuk menentukan maju atau mundurnya suatu bangsa.

Keberhasilan pendidikan suatu negara erat dikaitkan dengan kemampuan 
Kasih., Nyeneng., \& Distrik. - Efektivitas Model Pembelajaran Jigsaw ...

guru dalam menyampaikan materi. Rendahnya prestasi belajar siswa dikarenakan sebagian besar guru di Indonesia dalam melaksanakan pembelajaran IPA masih menggunakan model pembelajaran konvensional.

Hasil belajar yang masih rendah juga terjadi di SMP Negeri 28 Bandar Lampung, diketahui bahwa guru dalam proses pembelajaran IPA Fisika yang berlangsung masih menggunakan model pembelajaran konvensional yang bersifat teacher centered. Hal ini berdampak terhadap hasil belajar siswa yang sebagian besar belum mencapai Kriteria Ketuntasan Minimal (KKM) di sekolah yaitu sebesar 70 .

Pembelajaran menggunakan model konvesional disampaikan oleh guru dengan cara menjelaskan, memberi contoh, mengajukan pertanyaan, dan memberi tugas secara klasikal dan kegiatan siswa hanya mencatat penjelasan dari guru. Meskipun ada kegiatan diskusi terkesan kurang hidup (Musthofa, 2013). Hal tersebut mengakibatkan proses pembelajaran menjadi tidak menarik dan siswa kehilangan minat untuk belajar IPA fisika. Seharusnya pembelajaran yang disajikan dapat menarik minat siswa dan melibatkan siswa secara aktif dalam proses pembelajaran (student centered).

Upaya untuk mengatasi masalah tersebut adalah dengan menggunakan model pembelajaran kooperatif. Pembelajaran kooperatif adalah metode mengajar yang mengelompokkan siswa dalam kelompok-kelompok kecil untuk saling bekerjasama dalam memahami pelajaran (Jumarni et al., 2013). Dalam pembelajaran kooperatif siswa membagi tugas dan bersama-sama mengeluarkan pendapat untuk memecahkan masalah (Mehta \& Kulshrestha, 2014). Sehingga terjadi interaksi yang lebih luas, yaitu interaksi yang dilakukan antara guru dengan siswa, siswa dengan siswa, siswa dengan guru (Rusman, 2016). Dengan demikian siswa akan terlibat aktif dalam proses berpikir dan kegiatan pembelajaran. Model pembelajaran kooperatif memiliki berbagai macam jenis. Hal ini dapat memudahkan guru untuk memilih tipe yang sesuai dengan pokok bahasan, tujuan pembelajaran, suasana kelas, 
Kasih., Nyeneng., \& Distrik. - Efektivitas Model Pembelajaran Jigsaw ...

dan sarana yang dimiliki sekolah. anggota kelompok lain di dalam Salah satunya yaitu model kelompoknya (Fitriani et al., 2014). pembelajaran kooperatif tipe Jigsaw. Teknik Jigsaw berfokus pada Menurut hasil penelitian pengembangan kerjasama antar siswa Trisianawati, Judin dan Setiawan dan kerja tim melalui pembagian (2016) yang menerapkan model pembelajaran kooperatif tipe Jigsaw pada materi Vektor menunjukkan bahwa rata-rata hasil pretest siswa pada kelas eksperimen adalah 14,67 dan pada kelas kontrol adalah 13,13. Namun, setelah diberi perlakuan, hasil posttest siswa pada kelas eksperimen adalah 84,81 dan pada kelas kontrol adalah 76,13. Dengan demikian, model pembelajaran kooperatif tipe Jigsaw dinilai mampu meningkatkan hasil belajar siswa.

Pembelajaran Jigsaw sebagai model pembelajaran kooperatif, menurut hasil beberapa penelitian dapat meningkatkan keterampilan akademik, kompetensi sosial, perilaku dalam belajar, dan motivasi untuk belajar (Rachmah, 2017). Model pembelajaran kooperatif tipe Jigsaw merupakan model belajar dengan cara siswa dibagi dalam kelompok kecil yang bertanggung jawab atas penugasan bagian materi belajar dan mengajarkan bagian tersebut kepada tugas diantara siswa, terjadi melalui tanggung jawab masing-masing siswa (Şengül et al., 2014). Siswa tidak hanya mempelajari materi yang diberikan, tetapi juga harus siap mengajarkan materi tersebut kepada kelompoknya, sehingga kemampuan kognitif dan sosial siswa sangat diperlukan.

Pada model pembelajaran kooperatif tipe Jigsaw setiap siswa akan berperan sebagai anggota tim asal dan tim ahli. Dengan adanya tim asal dan tim ahli akan merangsang kerjasama diantara siswa sehingga efektif untuk memberikan pemahaman terhadap isi materi pembelajaran, menciptakan suasana belajar yang lebih baik, dan memiliki efek positif terhadap prestasi akademik. Langkah-langkah pembelajaran Jigsaw, yaitu: (1) siswa dibagi atas beberapa kelompok (tiap kelompok anggotanya 4-6 orang), (2) materi pelajaran diberikan kepada siswa dalam bentuk teks yang telah 
Kasih., Nyeneng., \& Distrik. - Efektivitas Model Pembelajaran Jigsaw ...

dibagi menjadi beberapa subbab, (3) setiap anggota kelompok membaca subbab yang ditugaskan dan bertanggung jawab untuk mempelajarinya, (4) anggota dari kelompok lain yang telah mempelajari subbab yang sama bertemu dalam kelompok ahli untuk mendiskusikannya, (5) setiap anggota kelompok ahli setelah kembali ke kelompoknya bertugas mengajar teman-temannya, kemudian (6) pada pertemuan dan diskusi kelompok asal, siswa dikenai tagihan berupa kuis individu (Al-Tabany, 2014). Dari langkah tersebut maka setiap siswa merupakan seorang ahli yang memiliki tanggung jawab individual dan kesempatan sukses yang sama dalam pembelajaran.Hubungan antara kelompok asal dan kelompok ahli digambarkan seperti Gambar 1 (AlTabany, 2014).
Melalui model pembelajaran ini diharapkan siswa dapat terlibat secara aktif dalam proses pembelajaran sehingga siswa lebih mudah memahami materi pelajaran, dan dapat mencapai tujuan pembelajaran serta dapat meningkatkan prestasi belajar siswa. Berdasarkan pemaparan masalah di atas, maka dilakukanlah penelitian guna mengetahui apakah terdapat pengaruh model pembelajaran kooperatif tipe Jigsaw terhadap hasil belajar IPA Fisika siswa kelas IX di SMP Negeri 28 Bandar Lampung.

\section{METODE}

Penelitian ini merupakan penelitian eksperimen semu (quasi eksperimen) dengan desain penelitian menggunakan Pretest-Posttest Control Group Design. Desain penelitian dapat dilihat pada Gambar 1.

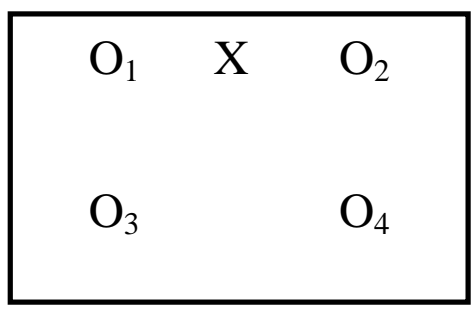

Gambar 1. Pretest-Posttest Control Group Design 
Kasih., Nyeneng., \& Distrik. - Efektivitas Model Pembelajaran Jigsaw ...

Desain penelitian menggunakan diberikan perlakuan. Pada kelas dua kelas, yaitu kelas eksperimen dan eksperimen diterapkan model kelas kontrol. Sebelum pembelajaran, pembelajaran kooperatif tipe Jigsaw diberikan pretest digunakan untuk sedangkan pada kelas kontrol menilai kemampuan awal siswa dan diterapkan model pembelajaran setelah mengikuti pembelajaran, konvensional. Ilustrasi model diberikan posttest digunakan untuk pembelajaran jigsaw dapat dilihat menilai hasil belajar siswa setelah pada gambar 2 .

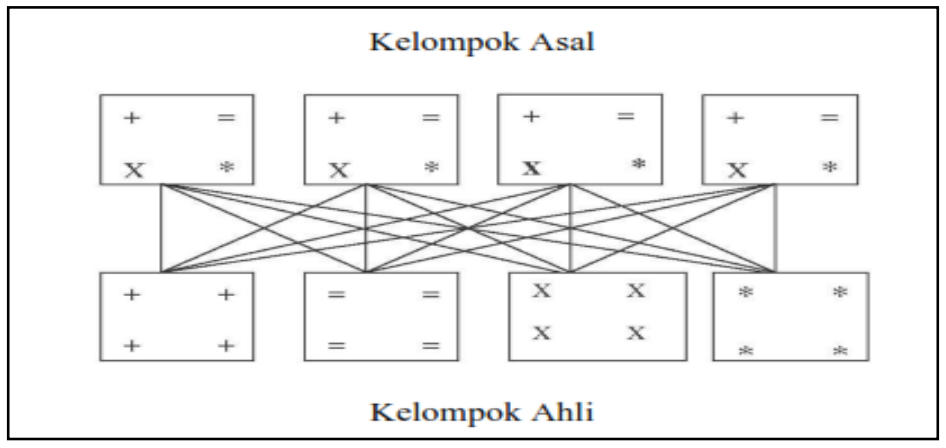

Gambar 2. Ilustrasi Model Jigsaw

Populasi dalam penelitian ini adalah seluruh siswa kelas IX SMP Negeri 28 Bandar Lampung pada semester genap tahun pelajaran 2017/2018 yang terdiri atas tujuh kelas dengan jumlah siswa 224 orang sedangkan sampel penelitian yang diambil adalah kelas IX B dan IX C dengan jumlah siswa 64 orang menggunakan teknik simple random sampling (sampel acak). Variabel dalam penelitian ini terdiri atas variabel bebas dan variabel terikat. Variabel bebas adalah model pembelajaran kooperatif tipe Jigsaw sedangkan variabel terikatnya adalah hasil belajar siswa.

Instrumen yang digunakan dalam penelitian ini adalah tes hasil belajar kognitif berupa soal pilihan jamak berjumlah 40 soal pada materi pokok Tata Surya. Instrumen yang telah diuji validitas dan reliabilitasnya kemudian diberikan kepada siswa pada saat pretest dan posttest pada kelas eksperimen dan kelas kontrol. Berdasarkan data yang diperoleh, peneliti melakukan analisis data 
Kasih., Nyeneng., \& Distrik. - Efektivitas Model Pembelajaran Jigsaw ...

dengan menhitung skor N-Gain hasil pretest dan posttest dari masingmasing kelas. Analisis uji statistik yang digunakan yaitu uji normalitas (Shapiro-Wilk), uji homogenitas, dan untuk menguji hipotesis digunakan uji Independent Sample T-Test dengan menggunakan bantuan program IBM SPSS 23 for Windows.

\section{HASIL DAN PEMBAHASAN}

Penelitian tentang pengaruh model pembelajaran kooperatif tipe Jigsaw terhadap hasil belajar siswa ini dilaksanakan di SMP Negeri 28 Bandar Lampung pada materi Tata Surya. Proses pembelajaran berlangsung sesuai dengan jadwal pelajaran IPA Fisika di sekolah dan dilakukan selama lima kali tatap muka dengan alokasi waktu 2 x 40 menit. Penelitian ini dilaksanakan pada kelas IX C sebagai kelas eksperimen dan kelas IX B sebagai kelas kontrol yang beranggotakan 32 siswa pada masing-masing kelas.

Pada kelas eksperimen diterapkan model pembelajaran kooperatif tipe Jigsaw dan pada kelas kontrol diterapkan model pembelajaran konvensional. Pada kelas eksperimen proses pembelajaran dilakasanakan dengan peneliti sebagai guru membuka pembelajaran dengan salam. Sebelum masuk pada materi pembelajaran guru memberikan motivasi dan pertanyaan apersepsi. Kemudian guru menayangkan sebuah video dan meminta siswa untuk menanggapi video yang telah ditayangkan. Setelah itu siswa melakukan studi pustaka untuk mencari dan menggali informasi dari buku maupun internet tentang materi yang akan dipelajari.

Selanjutnya guru membagi siswa menjadi 8 kelompok asal dengan anggota 4 orang tiap kelompok. Setelah itu guru membagi materi menjadi empat submateri. Kemudian siswa dari masing-masing kelompok mengambil undian materi tersebut dan siswa yang mendapatkan materi sama berkumpul untuk membentuk kelompok ahli untuk melakukan diskusi, mengumpulkan informasi, dan bertukar pendapat. Seluruh anggota kelompok ahli harus bertindak sebagai ahli yang aktif dan ikut serta dalam diskusi.

Setelah diskusi ahli selesai, siswa kembali ke kelompok asal dan 
Kasih., Nyeneng., \& Distrik. - Efektivitas Model Pembelajaran Jigsaw ...

mengajarkan kepada teman 1 dapat dilihat bahwa rata-rata pretest sekelompoknya mengenai materi yang diperoleh siswa sebelum yang telah didiskusikan di dalam diberikan perlakuan hanya sebesar 50 kelompok ahli. Tiap kelompok pada kelas eksperimen dan 40 pada membuat kesimpulan hasil diskusi kelas kontrol. Hal ini menunjukkan dan mempersiapkan presentasi. Salah kemampuan awal yang dimiliki siswa satu kelompok yang ditunjuk oleh dapat dikatakan rendah. Setelah guru dapat mempresentasikan hasil diberikan perlakuan, diketahui bahwa diskusinya, sementara kelompok kemampuan hasil belajar akhir siswa lainnya memberi tanggapan. Kemudian guru bersama siswa berupa rata-rata nilai posttest pada kelas eksperimen sebesar 90 dan pada menimpulkan hasil pembelajaran. Sebelum dan sesudah pembelajaran diberikan tes berupa pretest dan posttest. Instrumen yang diujikan pada siswa telah dinyatakan valid dan reliabel.

Data yang diperoleh dari penelitian ini merupakan data kuantitatif yang diperoleh berdasarkan hasil pretest dan posttest siswa. Berdasarkan Tabel kelas kontrol sebesar 76. Berdasarkan hasil tersebut dapat dilihat bahwa terjadi peningkatan terhadap hasil belajar siswa pada kedua kelas. Pada kelas eksperimen yang menerapkan model pembelajaran kooperatif tipe Jigsaw terjadi peningkatan yang lebih tinggi dibandingkan kelas kontrol yang menerapkan model pembelajaran konvensional.

Tabel 1. Data Hasil Pretest dan Posttest Siswa

\begin{tabular}{ccc}
\hline Parameter & Kelas Eksperimen & Kelas Kontrol \\
\hline Jumlah Siswa & 32 & 32 \\
Rata-rata Nilai Pretest & 50 & 40 \\
Rata-rata Nilai Posttest & 90 & 76 \\
\hline
\end{tabular}

Setelah diperoleh nilai pretest dan posttest, maka dapat dihitung nilai $\mathrm{N}$ Gain siswa untuk mengetahui ratarata peningkatan hasil belajar yang diperoleh siswa seperti yang dapat dilihat pada Tabel 2. Melalui perhitungan diperoleh dapat diketahui bahwa peningkatan hasil belajar siswa 
Kasih., Nyeneng., \& Distrik. - Efektivitas Model Pembelajaran Jigsaw ...

di kelas eksperimen yaitu sebesar N-Gain pada kelas eksperimen yaitu $39,5 \%$ lebih tinggi daripada sebesar 0,79 dengan kategori tinggi peningkatan hasil belajar siswa kelas dan pada kelas kontrol sebesar 0,61 kontrol yaitu sebesar 36,3\%. Rata-rata dengan kategori sedang.

Tabel 2. Data Rata-rata N-Gain Hasil Belajar Siswa

\begin{tabular}{ccc}
\hline Perolehan Nilai & Kelas Eksperimen & Kelas Kontrol \\
\hline Gain tertinggi & 63 & 68 \\
Gain terendah & 18 & 18 \\
Rata-rata Gain & 39 & 36 \\
Kenaikan nilai rata-rata & $39,5 \%$ & $36,3 \%$ \\
Rata-rata N-Gain & 0,79 & 0,61 \\
Kategori & Tinggi & Sedang \\
\hline
\end{tabular}

Setelah diperoleh skor penilaian yaitu 0,072 pada kelas eksperimen siswa, kemudian dilakukan uji dan 0,114 pada kelas kontrol sehingga normalitas terhadap perolehan skor dapat disimpulkan sampel penelitian N-Gain hasil belajar siswa yang digunakan berdistribusi normal. menggunakan metode Shapiro-Wilk. Hasil uji normalitas ini merupakan Berdasarkan Tabel 3 dapat diketahui salah satu syarat untuk melakukan uji bahwa nilai Sig. lebih besar dari 0,05 Independent Sample T-Test.

Tabel 3.Hasil Uji Normalitas Skor N-Gain

\begin{tabular}{lccc}
\hline Kelas & \multicolumn{3}{c}{ Shapiro-Wilk } \\
& Statistic & df & Sig. \\
\hline Eksperimen &, 939 & 32 &, 072 \\
Kontrol &, 946 & 32 &, 114 \\
\hline
\end{tabular}

Sebelum melakukan uji Tabel 4 dapat diketahui bahwa nilai Independent Sample T-Test, terlebih dahulu dilakukan uji homogenitas untuk mengetahui apakah varian data adalah sama atau tidak. Berdasarkan Sig. lebih dari 0,05 yaitu 0,111 sehingga dapat disimpulkan bahwa data memiliki varian yang sama (homogen). 
Kasih., Nyeneng., \& Distrik. - Efektivitas Model Pembelajaran Jigsaw ...

Tabel 4. Hasil Uji Homogenitas N-Gain

\begin{tabular}{cccc}
\hline Levene Statistic & $\boldsymbol{d f 1}$ & $\boldsymbol{d f 2}$ & Sig. \\
\hline 2,619 & 1 & 62 & 0,111 \\
\hline
\end{tabular}

Uji Independent Sample T-Test dilakukan untuk mengetahui ada atau tidak perbedaan rata-rata hasil belajar kelas eksperimen dengan kelas kontrol, dengan ketentuan data berdistribusi normal dan memiliki varian data yang sama. Pada Tabel 5 dapat diketahui bahwa nilai Sig. pada Levene's Test Equality of Variances yaitu sebesar 0,111 lebih besar dari 0,05 sehingga dapat dikatakan bahwa data tersebut memiliki varian yang sama. Karena data memiliki varian yang sama, maka nilai $t_{\text {hitung }}$ dan Sig(2-tailed) yang digunakan yaitu nilai yang terdapat pada kolom Equal
Variances Assumed. Nilai $t_{\text {hitung }}$ yang diperoleh yaitu sebesar 3,968 lebih besar dari $t_{\text {tabel }}$ yaitusebesar 1,999. Nilai Sig (2tailed) yang diperoleh adalah 0,0001 $<$ 0,05. Dari data yang diperoleh dapat diambil keputusan hipotesis nol ditolak. Hal ini menandakan bahwa terdapat perbedaan rata-rata hasil belajar siswa kelas eksperimen dan kelas kontrol, dimana hasil belajar siswa lebih tinggi setelah menggunakan model pembelajaran kooperatif tipe Jigsaw dibandingkan dengan menggunakan model pembelajaran konvensional.

Tabel 5. Hasil Uji Independent Sample T-Test

\begin{tabular}{lccc}
\hline & & \multicolumn{2}{c}{ Gain } \\
& & $\begin{array}{c}\text { Equal Variances } \\
\text { Assumed }\end{array}$ & $\begin{array}{c}\text { Equal Variances } \\
\text { Not Assumed }\end{array}$ \\
\hline $\begin{array}{l}\text { Levene's Test for Equality } \\
\text { of Varinces }\end{array}$ & $\mathrm{F}$ & 2,619 & \\
T-test for Equality of & $\mathrm{Sig}$ & 0,111 & \\
Means & $\mathrm{T}$ & 3,968 & 3,968 \\
& $\mathrm{Df}$ & 62 & 59,652 \\
& Sig (2-tailed) & 0,000 & 0,000 \\
\hline
\end{tabular}

Perbedaan rata-rata hasil belajar yang diperoleh siswa menunjukkan bahwa terdapat pengaruh model pembelajaran kooperatif tipe Jigsaw 
Kasih., Nyeneng., \& Distrik. - Efektivitas Model Pembelajaran Jigsaw ...

terhadap hasil belajar siswa. menggunakan teknik Jigsaw lebih Kemudian dengan menggabungkan efektif dibandingkan teknik hasil analisis rata-rata N-Gain, dapat instruksional yang berpusat pada dinyatakan bahwa pembelajaran guru. Dengan demikian, model menggunakan model pembelajaran pembelajaran tersebut efektif untuk kooperatif tipe Jigsaw dapat digunakan sebagai model berpengaruh meningkatkan hasil pembelajaran yang berpengaruh untuk belajarsiswa pada materi Tata Surya secara signifikan.

Hasil penelitian ini didukung oleh hasil penelitian yang dilakukan oleh Trisianawati et al. (2016) yang menyatakan bahwa penerapan model pembelajaran kooperatif tipe Jigsaw memiliki pengaruh terhadap peningkatan hasil belajar siswa pada materi vektor. Selain itu, hasil penelitian Çagatay dan Demircioglu (2013) menyatakan bahwa pembelajaran menggunakan model pembelajaran kooperatif tipe Jigsaw menunjukkan hasil yang lebih baik dibandingkan dengan pembelajaran menggunakan model pembelajaran tradisional. Kemudian berdasarkan hasil penelitian Iweka (2017) menyatakan bahwa terdapat perbedaan yang signifikan antarateknikJigsaw dengan teknik instruksional yang berpusat pada guru, sehingga pembelajaran meningkatkan hasil belajar siswa.

Pada proses pembelajaran pada kelas eksperimen yang diterapkan menggunakan model pembalajaran kooperatif tipe Jigsaw, siswa menunjukkan ketertarikan dengan turut serta berperan aktif dalam mencari dan mengolah informasi dari berbagai sumber terkait materi Tata Surya yang dipelajari. Selama proses pembelajaran berlangsung, siswa aktif bekerjasama di dalam kelompok ahli maupun kelompok asal untuk menemukan makna pembelajaran dan terdorong untuk belajar secara mandiri. Siswa pun bertanggung jawab untuk memahami dan mengerti tentang materinya masing-masing. Sedangkan proses pembelajaran pada kelas kontrol yang diterapkan menggunakan model pembelajaran konvensional, proses pembelajaran lebih berpusat pada guru, hal ini mengakibatkan siswa-siswa menjadi 
Kasih., Nyeneng., \& Distrik. - Efektivitas Model Pembelajaran Jigsaw ...

tidak aktif terlibat dalam proses dalam keberhasilan suatu pembelajaran yang menghasilkan kurangnya pemahaman siswa akan materi yang diajarkan sehingga hasil belajar kurang maksimal.

Keberhasilan pelaksanaan model pembelajaran kooperatif tipe Jigsaw ini dikarenakan adanya kontribusi dari kelompok ahli. Hasil penelitian Setyaningsih, Jalmo Tri, dan Yolida (2014) menyatakan bahwa setiap anggota kelompok ahli dituntut untuk memberikan kontribusi terhadap keberhasilan anggota tim asal. Oleh karena itu, setiap anggota tim ahli harus memiliki tanggung jawab sesuai dengan tugasnya. Didukung oleh hasil penelitian Vanalita, Jalmo, dan Marpaung (2014) yang menyatakan bahwa pada saat berada pada kelompok ahli siswa mempunyai kesempatan untuk mendiskusikan dengan siswa lain dengan materi yang sama. Dengan mendiskusikan materi yang sama, siswa menjadi lebih ahli dan lebih memahami isi materi tersebut sehingga siswa dapat lebih mudah dalam menyampaikan materi kepada anggota kelompok asal. Sehingga dapat dikatakan bahwa tim ahli memiliki peranan yang besar pembelajaran dengan menggunakan model pembelajaran kooperatif tipe Jigsaw.

Hasil penelitian Maryani, Pargito., dan Lusi (2014) menyatakan bahwa model pembelajaran kooperatif tipe Jigsaw merupakan model pembelajaran yang diterapkan agar siswa memiliki banyak kesempatan untuk mengemukakan pendapat dan mengolah informasi. Didukung oleh hasil penelitian Ruwanti dan Yolida (2014) yang menyatakan bahwa model pembelajaran kooperatif tipe Jigsaw lebih menuntut kemandirian dan tanggung jawab lebih besar dalam melaksanakan pembelajaran. Kemudian Trisianawati, et al. (2016) menyatakan bahawa dengan menerapkan model pembelajaran kooperatif tipe Jigsaw, siswa tidak hanya memperoleh pengetahuan berupa pengetahuan kognitif, tetapi siswa juga memiliki keterampilan dalam berinteraksi dengan teman sekelas. Selain itu siswa menjadi lebih aktif dan kreatif.

Model pembelajaran kooperatif tipe Jigsaw sangat baik diterapkan. Dengan menggunakan model 
Kasih., Nyeneng., \& Distrik. - Efektivitas Model Pembelajaran Jigsaw ...

tersebut, seorang siswa akan benarbenar mendalami materi yang dipelajari. Mereka juga dituntut supaya mampu menjadi tutor bagi teman-teman dalam kelompoknya. Model pembelajaran kooperatif ini juga mengajak siswa untuk lebih aktif dalam proses pembelajaran dan bersungguh-sungguh dalam mempelajari dan memahami suatu materi yang sedang diajarkan. Dengan keaktifan siswa yang lebih dominan, maka siswa dapat memahami materi yang diajarkan sehingga dapat meningkatkan hasil belajar IPA Fisika siswa terutama pada materi Tata Surya.

\section{KESIMPULAN DAN SARAN}

Berdasarkan hasil penelitian dan pembahasan yang telah dipaparkan, maka dapat disimpulkan bahwa terdapat pengaruh model pembelajaran kooperatif tipe Jigsaw terhadap hasil belajar siswa, dibuktikan dengan adanya perbedaan rata-rata hasil belajar siswa yang signifikan. Model pembelajaran kooperatif tipe Jigsaw berpengaruh sangat baik dalam meningkatkan hasil belajar siswa, dibuktikan dengan peningkatan hasil belajar siswa dan perolehan $\mathrm{N}$-Gain yang tinggi pada kelas eksperimen yang diterapkan menggunakan model tersebut.

Berdasarkan simpulan yang diperoleh, maka saran yang dapat dikemukakan yaitu: (1) Guru dalam menyajikan materi fisika menggunakan beragam model pembelajaran yang inovatif, salah satunya yaitu model pembelajaran kooperatif tipe Jigsaw yang dapat dijadikan alternatif bagi guru di sekolah dalam upaya meningkatkan hasil belajar siswa. (2) Guru dapat mengkondisikan siswa supaya pembelajaran dapat berjalan dengan baik dan alokasi waktu sesuai dengan rencana pembelajaran sehingga tujuan pembelajaran dapat tercapai.

\section{DAFTAR PUSTAKA}

Al-Tabany, T. I. B. 2014. Mendesain Model Pembelajaran Inovatif, Progresif, dan Kontekstual: Konsep, Landasan, Implementasinya pada Kurikulum 2013 (Kurikulum Tematik Integratif/KTI). Jakarta: Kencana.

Çagatay, G., \& Demircioglu, G. (2013). The Effect of Jigsaw-I Cooperative Learning Technique on Students' Understanding about Basic Organic Chemistry Concepts. The International 
Kasih., Nyeneng., \& Distrik. - Efektivitas Model Pembelajaran Jigsaw ...

Journal of Educational

Researchers. 4, (2), 30 -37.

Fitriani, C. R., Jalmo T., \& Marpaung R. R. T. (2014). Perbandingan Penggunaan Model STAD dan Jigsaw Terhadap Aktivitas Belajar dan Penguasaan Materi. Jurnal Bioterdidik: Wahana Ekspresi Ilmiah. 2,(1), 114.

Iweka, F. (2017). Effects of Authentic and Jigsaw II Learning Techniques on Students Academic Achievement in Mathematics. Global Journal of Arts, Humanities and Social Sciences. 5, (5), 18 - 24.

Jumarni, S., Sarwanto., \& Masithoh, D. F. (2013). Penerapan Pembelajaran Fisika Model Kooperatif Tipe Jigsaw Untuk Meningkatkan Aktivitas dan Hasil Belajar Fisika Siswa di SMP. Jurnal Pendidikan Fisika. 1, (2), 34-40.

Maryani, D. I., Pargito., \& Lusi, I. (2014). Efektivitas Model Pembelajaran Kooperatif Tipe Jigsaw Terhadap Prestasi Belajar Geografi. Jurnal Penelitian Geografi. 2, (3), 1-11.

Mehta, S., \& Kulshrestha, A. K. (2014). Implementation of Cooperative Learning In Science: A Developmental-cumExperimental Study. Journal of Educational

Research International.

Musthofa, K. (2013). Pembelajaran Fisika Dengan Cooperative Learning Tipe Jigsaw Untuk Mengoptimalkan Aktivitas dan Kemampuan Kognitif Siswa Kelas X-6 SMA MTA Surakarta.
Jurnal Pendidikan Fisika. 1, (1), 55-63.

Rachmah, D. N. 2017. Effect of Jigsaw Method on Students Self Efficacy and Motivation to Learn. Journal of Educational, Health, and Community Psychology. 6, (3), 1-9.

Rusman. (2016). Model-Model Pembelajaran: Mengembangkan Profesionalime Guru (Edisi Kedua). Jakarta: Rajawali Pers.

Ruwanti, J, T., \& Yolida, B. (2014). Pengaruh Pembelajaran Kooperatif Tipe STAD dan Jigsaw Terhadap Penguasaan Materi Oleh Siswa. Jurnal Bioterdidik: Wahana Ekspresi Ilmiah. 2, (3), 1-13.

Şengül, S., \& Katranci, Y. (2014). Effects of Jigsaw Technique on Seventh Grade Primary School Students' Asttitude towards Mathematics. Procedia - Social and Behavioral Science. 116, (2014), 339 - 344.

Setyaningsih, C. A., Jalmo Tri., \& Yolida, B. (2014). Kontribusi Anggota Tim Ahli dalam Pembelajaran Kooperatif Tipe Jigsaw Terhadap Hasil Belajar. Jurnal Bioterdidik: Wahana Ekspresi Ilmiah. 2, (7), 1-13.

Trisianawati, E., Djudin, T., \& Setiawan, R. (2016). Pengaruh Model Pembelajaran Kooperatif Tipe Jigsaw Terhadap Hasil Belajar Siswa Pada Materi Vektor di Kelas X SMA Negeri 1 Sanggau Ledo. Jurnal Penelitian Fisika dan Aplikasinya. 6, (2), 5160. 
Kasih., Nyeneng., \& Distrik. - Efektivitas Model Pembelajaran Jigsaw ...

Vanalita, M., Jalmo, T., \& Marpaung, R. R. T. (2014).

Pengaruh Model Pembelajaran

Jigsaw Terhadap Kemampuan

Komunikasi Lisan dan Hasil

Belajar Siswa. Jurnal Bioterdidik:

Wahana Ekspresi Ilmiah. 2, (9), 1-

17. 